\title{
Diplopia After Coronary Revascularization
}

\section{Diplopia Após Procedimento de Revascularização Coronária}

Joana BRAGA ${ }^{1}{ }^{1}$, Filipe NEVES ${ }^{1}$, João $\operatorname{COSTA}^{1}$, Dália MEIRA ${ }^{1}$

Acta Med Port 2020 Oct;33(10):685-688 - https://doi.org/10.20344/amp.11751

ABSTRACT

Percutaneous coronary intervention is a coronary revascularization procedure that may rarely result in thromboembolic events. Although infrequent, ophthalmological complications of percutaneous interventions include a wide range of clinical presentations, with differing severity and outcomes. In this case report, an 83-year-old woman, with multiple cardiovascular risk factors, presents with horizontal diplopia after a percutaneous transluminal coronary angioplasty. After ophthalmological evaluation and a head computed tomography scan, the diagnosis of isolated ischemic internuclear ophthalmoplegia was established. After six months of follow-up, the patient showed complete recovery of her symptoms and ocular movements. We discuss the post-percutaneous intervention ophthalmic complications that, although uncommon, must be recognized by health care providers.

Keywords: Diplopia; Myocardial Revascularization; Ocular Motility Disorders; Percutaneous Coronary Intervention

\section{RESUMO}

A intervenção coronária percutânea é um procedimento de revascularização coronária que pode, raramente, resultar em eventos tromboembólicos. Apesar de incomuns, as complicações oftalmológicas da intervenção percutânea incluem um largo espectro de manifestações clínicas com diferentes prognósticos. Reportamos um caso clínico de uma mulher de 83 anos, com múltiplos fatores de risco cardiovascular, que apresenta diplopia horizontal após uma angioplastia coronária percutânea. O diagnóstico de oftalmoplegia internuclear isquémica isolada foi estabelecido após avaliação oftalmológica e realização de tomografia computorizada cranioencefálica. Seis meses após a apresentação, a doente apresentava recuperação completa dos sintomas e dos movimentos oculares. Os autores discutem as complicações oftalmológicas da intervenção percutânea que, apesar de incomuns, devem ser reconhecidas pelos profissionais de saúde.

Palavras-chave: Diplopia; Intervenção coronária percutânea; Revascularização Miocárdica; Transtornos da Motilidade Ocular

\section{INTRODUCTION}

Cardiovascular disease is the leading cause of mortality worldwide. ${ }^{1}$ Percutaneous coronary intervention (PCI), or coronary angioplasty, is performed to diagnose and treat significant coronary artery disease (CAD). ${ }^{2}$ Although less invasive than coronary artery bypass grafting, $\mathrm{PCl}$ is associated with some complications, mainly thromboembolic events, leading to organ infarction..$^{3,4}$ Ophthalmological complications of $\mathrm{PCl}$ include a wide spectrum of clinical manifestations, ranging from transient visual disturbances to permanent and devastating situations. These complications tend to occur in the immediate postoperative period and urgent treatment may prevent permanent vision loss. ${ }^{3,4}$

We report a case of post- $\mathrm{PCl}$ acute diplopia resulting from internuclear ophthalmoplegia (INO) and discuss the risks and management of post- $\mathrm{PCl}$ ophthalmological complications.

\section{CASE REPORT}

An 83-year-old woman with coronary heart disease, type 2 diabetes mellitus, hypertension and dyslipidaemia, underwent elective $\mathrm{PCl}$ with everolimus-eluting stent placement in the anterior descending artery. Within 24 hours after the procedure, the patient developed isolated horizontal diplopia on the right gaze. Upon ophthalmologic evaluation, the patient presented a best-corrected visual acuity of $5 / 10$ in both eyes and intraocular lens posterior capsule opaci- fication. Neuro-ophthalmic evaluation revealed adduction limitation of the left eye and abduction nystagmus of the right eye (Fig. 1). Convergence and other eye movements were intact. There was no anisocoria, pupillary light reflex deficits or ptosis. No other neurological signs were found.

Emergent computed tomography (CT) scan of the brain showed normal findings for the patient's age. The clinical findings were consistent with left INO, probably caused by an ischemic embolic event following $\mathrm{PCl}$. The patient was discharged with the recommended double antiplatelet therapy after drug-eluting stent implantation and kept under observation with regular consultations.

During the first six months of follow up, the patient's symptoms improved progressively with a complete resoIution of the diplopia. Ophthalmological re-evaluation revealed normal ocular movements without nystagmus (Fig. 2).

\section{DISCUSSION}

The conjugate horizontal movements of the eyes are mediated by the paramedian pontine reticular formation (PPRF), which receives information from the contralateral frontal lobe and projects to the ipsilateral abducens nucleus $(\mathrm{nVl})$. Motor neurons of the $\mathrm{nVI}$, are responsible for the stimulus of the lateral rectus muscle. Interneurons of the $\mathrm{nVI}$ cross the midline, travel through the medial longitudinal

1. Ophthalmology Department. Centro Hospitalar Vila Nova de Gaia / Espinho. Vila Nova de Gaia. Portugal.

$\triangle$ Autor correspondente: Joana Braga. jfbraga6@hotmail.com

Recebido: 28 de dezembro de 2018 - Aceite: 25 de fevereiro de 2019 | Copyright @ Ordem dos Médicos 2020 

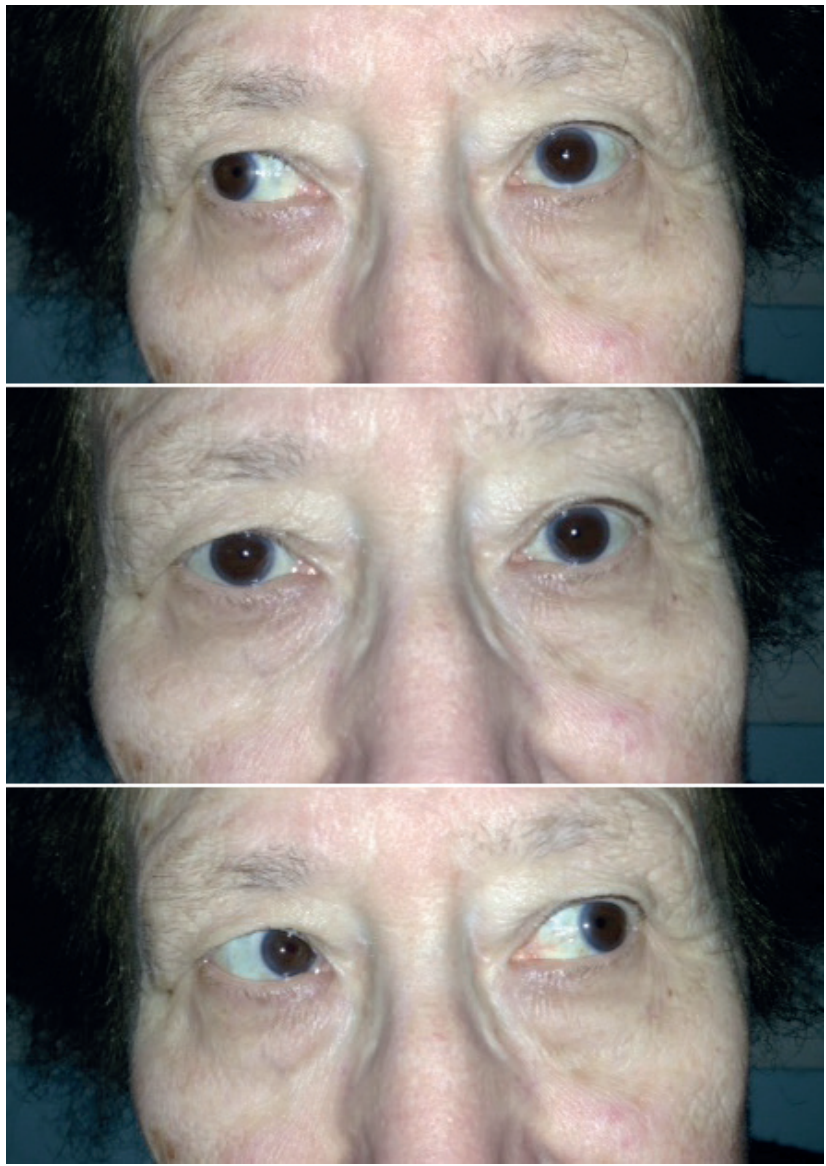

Figure 1 - Photographs of ocular movements at presentation

fasciculus (MLF) in the dorsomedial brainstem, and project in the contralateral medial rectus subnucleus of the oculomotor nuclear complex (nIII). ${ }^{5}$ Therefore, the activation of the $\mathrm{nVI}$ generates ipsilateral horizontal gaze (see Fig. 3).

A lesion in the MFL affects the conjugate movements and causes INO. This is one of the most localized brainstem syndromes, and manifests with ipsilateral adduction deficit and abduction nystagmus of the contralateral eye when gazing to the side opposite the lesion. The most common symptom is horizontal diplopia on conjugate lateral gaze and other clinical findings may be present according to the extent of the lesion and its location. ${ }^{5,6}$ The MFL is irrigated almost exclusively by end-arteries from small perforating arteries originating at the top of the basilar artery. Because of this vascular supply, it is particularly vulnerable to ischemia and microemboli. ${ }^{7}$

Isolated INO related to $\mathrm{PCl}$ accounted for $4.5 \%$ of a series of 110 patients diagnosed with INO. ${ }^{8}$ In this setting, INO may result from ischemia in the context of microembolization or thrombosis related with hypotension, pre-existing vascular disease or dehydration. INO related with $\mathrm{PCl}$ showed good prognosis with resolution of diplopia in a few months. ${ }^{8}$

Several other ophthalmic complications arising from $\mathrm{PCl}$ have been reported in the literature. These events include retinal complications and neuro-ophthalmic complications.

Retinal complications range from asymptomatic findings
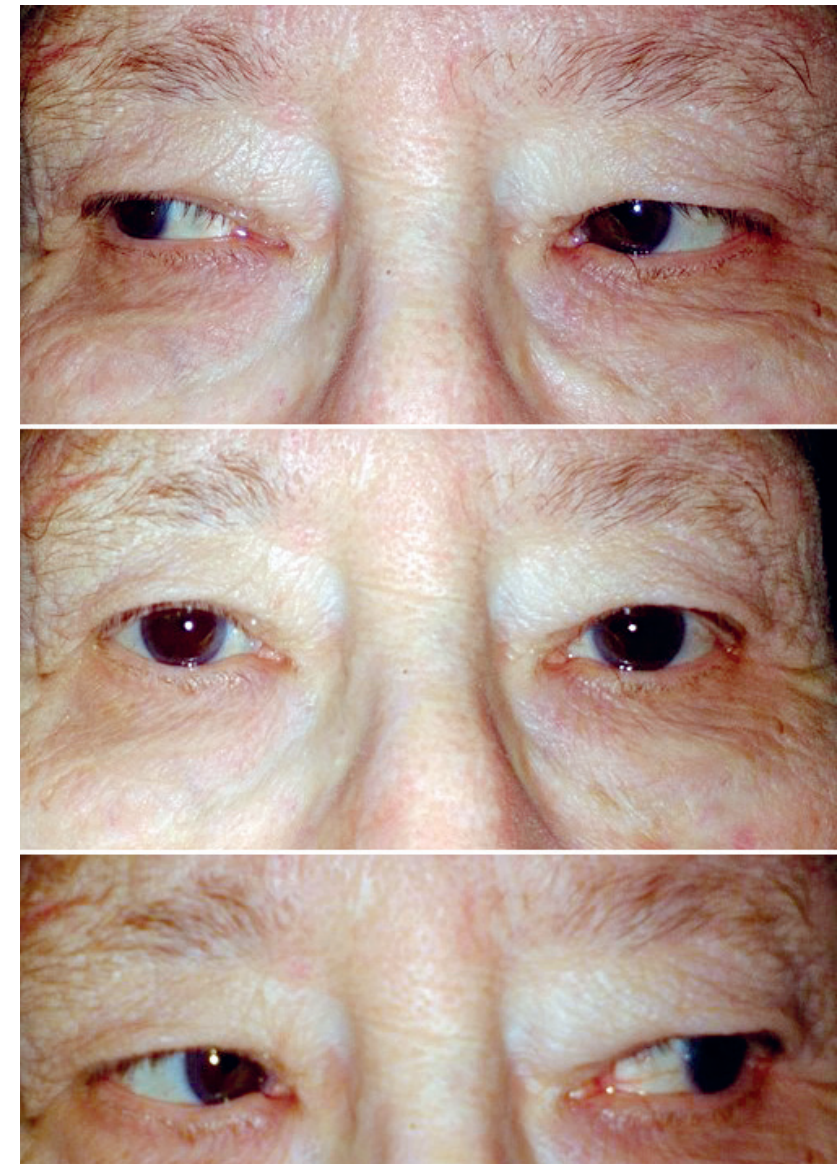

Figure 2 - Photographs of ocular movements six months after presentation

(cotton wool spots and superficial haemorrhages) to severe retinal thromboembolic events with vision loss. ${ }^{2,4,5}$ New retinal microemboli have been reported with an incidence ranging from $0 \%$ to $15 \%$ after heart catheterization procedures. ${ }^{2}$ Kojuri et al reported an incidence of $6.33 \%$ in new post-PCI retinal emboli in asymptomatic patients. With the ophthalmic artery being the first major branch of the internal carotid artery, emboli originating from atheromatous plaques, thrombus of the catheter tip, and, rarely, foreign materials from the catheter or guide wire, may travel from the heart towards the eyes. ${ }^{4}$ Severe thromboembolic events in the eyes include branch retinal artery occlusion (BRAO) and central retinal artery occlusion (CRAO). Retinal artery occlusion is an ophthalmological emergency since immediate reperfusion of retinal vessels, within six hours, is believed to reverse or reduce tissue damage and prevent permanent lesions. ${ }^{3}$

Neuro-ophthalmological complications of $\mathrm{PCI}$ may arise from thromboembolic events in several important nuclei of ocular motility, ${ }^{2}$ including isolated partial third nerve palsy; ${ }^{9}$ partial lateral rectus palsy; ${ }^{10}$ and bilateral ophthalmoplegia. ${ }^{11}$ Supranuclear ophthalmoplegia ${ }^{12}$ and skew deviation ${ }^{13}$ have also been reported following $\mathrm{PCl}$.

Another important neuro-ophthalmological complication is cortical blindness, with an estimated incidence of $0.05 \%-1 \%$, which manifests as an acute loss of vision 


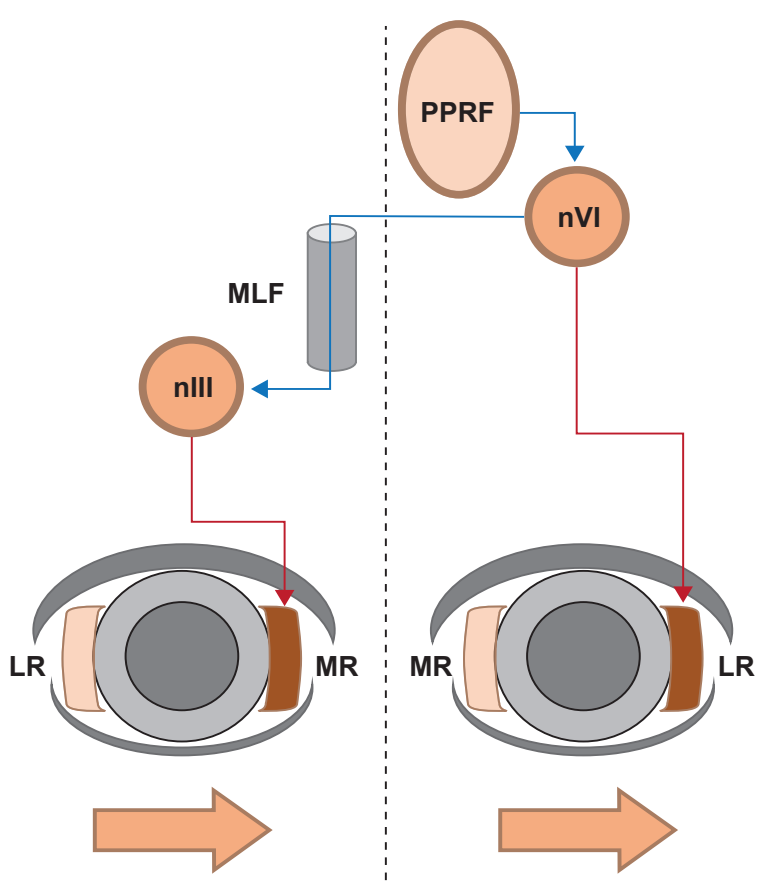

Figure 3 - MLF pathway

PPRF: paramedian pontine reticular formation; $\mathrm{nVI}$ : abducens nucleus; $\mathrm{nlll}$ : oculomotor nuclear complex; MLF: medial longitudinal fasciculus; LR: lateral rectus muscle; MR: medial rectus muscle.

immediately after the procedure, usually with complete recovery in the following days. Although its pathophysiology remains uncertain, it is thought to result from occipital cortex damaged by contrast agents due to a focal permeability of the blood-brain barrier. ${ }^{14,15}$

Diplopia or other ocular symptoms in patients that underwent a recent coronary revascularization procedure warrant urgent ophthalmological consultation. Ophthalmological and systemic evaluation, as well as a CT scan of the brain, are indicated to rule out differential diagnoses, namely other cerebral vascular events. CT scan is also essential for the diagnosis of contrast-induced neurotoxicity. ${ }^{2,3}$

Special attention must be given to high risk cases, namely: older patients, the presence of systemic comorbidities

\section{REFERENCES}

1. Mozaffarian D, Benjamin EJ, Go AS, Arnett DK, Blaha MJ, Cushman M, et al. Heart disease and stroke statistics 2015 update: a report from the American Heart Association. Circulation. 2015;131:e29-322.

2. Lau E, Ilsen PF. Ophthalmic complications of coronary revascularization: a review of literature. Clin Refract Optom Online. 2015;26:1.

3. Hsien YM, Mustapha M, Hamzah JC, Maskon O, Ken CC, Hamdi $\mathrm{CH}$. Why can't I see after my heart is fixed: a case series of ocular complications after cardiac intervention. BMC Ophthalmol. 2016;16:32.

4. Kojuri J, Mehdizadeh M, Rostami H, Shahidian D. Clinical significance of retinal emboli during diagnostic and therapeutic cardiac catheterization in patients with coronary artery disease. BMC Cardiovasc Disord. 2011;11:5.

5. Lemos J, Meira D. Distúrbios supra e internucleares da motilidade ocular; Neuroftalmologia baseada na evidência. In: Neuroftalmologia baseada na evidência. Lisboa: Sociedade Portuguesa de Oftalmologia; 2014.

6. Frohman TC, PA-C, Frohman EM. UptoDate. Internuclear ophthalmoparesis. [accessed 2018 Jan 18]. Available from: www.uptodate.com https://www.uptodate.com/contents/ (for example, hypertension, diabetes mellitus) and specific heart conditions (associated arrhythmia, hypokinetic wall, intramural thrombus and extension of left main stem artery). ${ }^{3,9}$ Additional risk factors, including operator expertise ${ }^{3}$ and prolonged and technically difficult procedures, ${ }^{9}$ have been identified in some studies. Specific risk factors, including impaired renal function and hyperosmolar iodinated contrast agents have been associated with cortical blindness. ${ }^{15}$

\section{CONCLUSION}

In conclusion, post-PCl ophthalmological complications are infrequent and vary from a wide range of presentations and severity. Patients and their health care providers must be alert to any visual disturbances after cardiac catheterization. In most cases, the prognosis is generally favourable, with complete recovery from the initial signs or symptoms.

\section{PROTECTION OF HUMANS AND ANIMALS}

The authors declare that the procedures were followed according to the regulations established by the Clinical Research and Ethics Committee and to the 2013 Helsinki Declaration of the World Medical Association.

\section{DATA CONFIDENTIALITY}

The authors declare having followed the protocols in use at their working center regarding patients' data publication.

\section{PATIENT CONSENT}

Obtained.

\section{CONFLICTS OF INTEREST}

All authors report no conflict of interest.

\section{FUNDING SOURCES}

This research did not receive any specific grant from funding agencies in the public, commercial, or not-for-profit sectors.

internuclear-ophthalmoparesis ? search $=$ Internuclear $\% 20$ ophthalmoparesis\&source=search_result\&selectedTitle=1 22\&usage _ type=default\&display_rank=1,

7. Hassler O. Arterial pattern of human brainstem: normal appearance and deformation in expanding supratentorial conditions. Neurology. 1967;17:368-75

8. Eggenberger E, Desai N, Kaufman D, Pless M. Internuclear opthalmoplegia after coronary artery catheterization and percutaneous transluminal coronary ballon angioplasty. J Neuroophthalmol. 2000;20:123-6.

9. Kocabay G, Bayram T. Unilateral isolated partial oculomotor nerve paralysis after percutaneous intervention. Angiology. 2009;60:3.

10. Nicholson L, Jones R, Hughes DS. Lateral rectus palsy following coronary angiography and percutaneous coronary intervention. BMJ Case Rep. 2014;2014: pii:bcr2013202307.

11. Drummond GT, Wuebbolt G. Bilateral ophthalmoplegia during percutaneous transluminal coronary angioplasty. Can J Ophthalmol. 1990;25:152-5.

12. Glisson C, Eggenberger E, Miller N. Supranuclear ophthalmoplegia as a 
complication of coronary angiography. J Neuroophthalmol. 2006;30:4.

13. Suzuki T, Nishio M, Chikuda M, Takayanagi K. Skew deviation as a complication of cardiac catheterization. Am J Ophthalmol. 2001;132:2.

14. Tatli E, Buyuklu M, Altun A. An unusual but dramatic complication of coronary angiography: Transient cortical blindness. Int J Cardiol. 2007;121:e4-6.

15. de Lara JG, Vázquez-Rodríguez J, Salgado-Fernández J, CalvinoSantos R, Vázquez-González N, Castro-Beiras A. Transient cortical blindness following cardiac catheterization: an alarming but infrequente complication with a good prognosis. Rev Esp Cardiol. 2008;61:88-90.

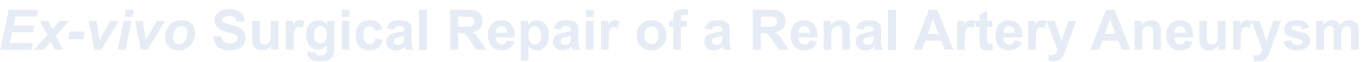

Goncalo SOBRINHOM1,2, Augusto MINISTRO1,2, Artur SILVA3,4, Luís PEDRO1

Acta Med Port 2020 Oct;33(10):688-691

ABSTRACT

Renal artery aneurysms are rare. They are most commonly degeneratiy

ex-vivo surgical repair, also knowr

put back in place. A 6

Keywords: Aneurysm/surgery; Kidney Transplantation; Renal Artery/surgery; Transplantation, Autologous

\section{RESUMO}

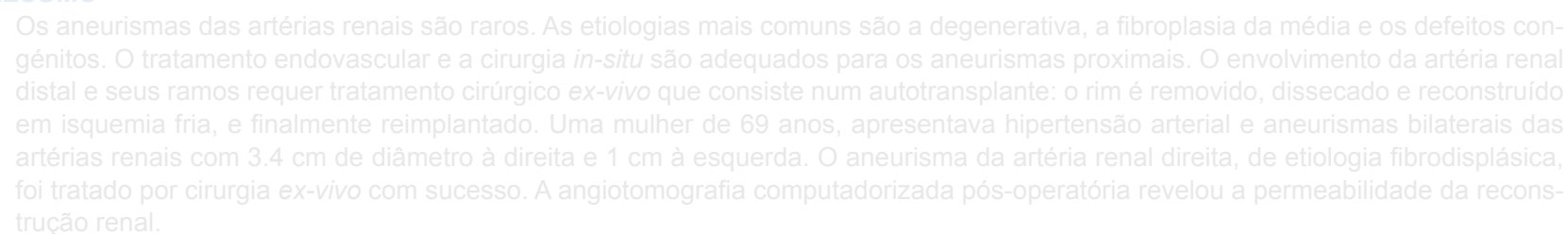

Palavras-chave: Aneurisma/cirurgia; Artéria Renal/cirurgia; Transplante Autólogo; Transplante de Rim

\section{INTRODUCTION}

Renal artery aneurysms are rare. They are most commonly degenerative, congenital or due to medial fibroplasia. ${ }^{1}$ Proximal aneurysms can be repaired by endovascular and in-situ surgical techniques. However, aneurysms of the distal renal artery and its branches require ex-vivo surgical repair, also known as auto-transplantation: the kidney is removed, dissected and reconstructed in cold ischemia, and put back in place.

\section{CLINICAL CASE}

A 69-year-old Caucasian female presented with controlled hypertension (on four anti-hypertensive drugs), dyslipidemia, acute myocardial infarction (with a normal coro-
nary angiography one year before), obesity, obstructive sleep apnea syndrome treated with continuous positive airway pressure (CPAP). She had a 40 pack-year smoking history until the age of 44 . In the workup for bilateral low back pain, a computed tomography angiography (CTA) revealed bilateral renal artery aneurysms (Fig. 1). Glomerular filtration measured by renal scintigraphy with 99 mTC-DTPA was $54 \mathrm{~mL} / \mathrm{min}$ (right), $46 \mathrm{~mL} / \mathrm{min}$ (left) and there was right excretory delay without significant mechanical obstruction. Serum creatinine was $0.90 \mathrm{mg} / \mathrm{dL}$ and hemoglobin was $10.3 \mathrm{~g} / \mathrm{dL}$. The ultrasound scan of the carotid and vertebra arteries showed no changes.

Ex-vivo surgical repair of the right renal aneurysm was carried out because the aneurysm involved the branches of the renal artery. This technique has been described in detail. ${ }^{2-5}$ A right retroperitoneal flank lazy-S shaped incision extending from the tip of the $11^{\text {th }}$ rib to an area just media to the McBurney point was used. The kidney was removed without dividing the ureter, encompassing a small ellipse of gitudinally) to allow for a patch anastomosis, placed on the patient's abdomen, immersed in ice slush and perfused with. Celsior solution at $4^{\circ} \mathrm{C}$. The hilum was dissected and three branches distal to the aneurysm were identified. The two cephalic branches were syndactylized and the combined 